\title{
Determinants of the quality of internet investor relations - a study of companies listed on the $\mathrm{JSE}^{\#}$
}

\author{
G.F. Nel ${ }^{a \star}$, E.vdM. Smit ${ }^{\mathrm{b}}$ and L.M. Brummer ${ }^{\mathrm{c}}$

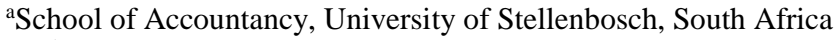 \\ bUniversity of Stellenbosch Business School, South Africa \\ ${ }^{\mathrm{c}}$ Department of Financial Management, University of Pretoria, South Africa \\ *To whom all correspondence should be addressed \\ gfn@sun.ac.za
}

\begin{abstract}
Investor relations is the field of management that is concerned with the relationships between companies and investors, and as such involves a wide variety of information types, for example mandatory, voluntary, financial, non-financial, qualitative and quantitative. While South Africa has recently been ranked number one for the strength of its auditing and reporting standards for the seventh consecutive year (IRBA, 2016), investor relations as a wider and voluntary concept, is largely unresearched in South Africa. The purpose of the study was to establish the determinants of Internet investor relations (IIR).
\end{abstract}

The quality of IIR was measured for a sample of 85 JSE-listed companies using a measurement instrument that consists of 346 attributes. From the literature, as discussed in the literature review, 15 company characteristics were identified that could explain IIR quality. Stepwise regression model-building was used to develop a regression model that best explains IIR quality.

Company size, leverage, being audited by a big four audit company, JSE industry membership, free float and dual listing status were found statistically significant independent variables, explaining $68.76 \%$ of the variation in the dependent variable, IIR. Contributions to the body of knowledge, study limitations and the need for further research are discussed in the conclusion.

\section{Introduction}

Granting that several investor relations communication channels are available to companies, for example, presentations, media releases, Twitter, Facebook and corporate websites, the current study examines only one of these channels, namely the corporate website. While JSElisted companies are mandated by various standards, acts and codes to communicate specific information items to investors (e.g. the integrated annual report), the decision to use the corporate website as investor relations communication channel is voluntary in nature. This study defines Internet investor relations (IIR) as the use of the corporate website to enhance investor relations.

The purpose of this study was to to establish the determinants of IIR. To date, studies examining JSE-listed companies have been limited to mere descriptive studies (Stainbank, 2000; Venter, 2002; Loxton, 2003; Barac, 2004; Nel \& Baard, 2007; Esterhyse \& Wingard, 2016).

The current study used a measurement instrument that consists of 346 attributes to measure IIR. More specifically,

\footnotetext{
\# The editor thanks prof $\mathrm{N}$ Wesson who has acted as editor for this article.

${ }^{1}$ For example, the average number of hours needed in the current study to measure the IIR per company was seven hours.
}

quality is measured by first of all measuring content as widely as possible, by measuring the presentation of information (accessibility, timeliness and navigation), and, finally, by allowing for the measurement of attributes as only partially available (scored as 0.5) based on breadth, timeliness and usability. For a detailed discussion of this measurement instrument, see Nel and Brummer (2016).

Given the labour-intensity ${ }^{1}$ of using such a measurement instrument, a sample of $25 \%$ of JSE-listed companies ${ }^{2}$ was selected using stratified (JSE industry) random sampling with proportionate allocation. A total of 85 companies were included in the sample. All IIR measurements were done from March to September 2015.

It was found that larger companies, companies with more debt, companies that are audited by a big four audit company, companies with a higher free-float percentage and, lastly, companies that were dual-listed had higher IIR scores. Companies that were members of one of the following four JSE industries, namely consumer services, consumer goods, financials, and technology, each had a lower IIR score

\footnotetext{
2 The population was defined as all companies listed on the JSE as on 30 September 2014, that had not been suspended, had traded since inception date, had published 2013 annual reports, and had a dedicated, working website.
} 
compared to companies listed in one of the other nine industries.

The remainder of this article is divided into four sections: a literature review, methodology, results and finally, conclusions are drawn and further research avenues proposed.

\section{Literature review}

The literature can be categorised as descriptive, determinant or effect studies. Descriptive studies measure and describe the use of the corporate website as communication channel. Determinant and effect studies, on the other hand, explore respectively the determinants and the consequences (effect) of the use of the corporate website. Determinant and effect studies can be further classified in terms of the proxy used for disclosure, i.e. indirect proxy that is not based on an examination of the original disclosure vehicle or a direct disclosure proxy. Direct disclosure proxy studies as such, can be classified in terms of the disclosure medium studied (e.g. an annual report or corporate website). It should further be noted that not all prior studies that have examined the use of the corporate website as communication channel have explicitly measured investor relations. This section discusses variables that were tested in the literature as independent variables to explain variations in disclosure levels.

\section{Company size}

Company size is the most widely used variable in the literature to explain disclosure levels (Celik, Ecer \& Karabacak, 2006: 107). With a few exceptions, almost all studies show a significant positive relationship between size and disclosure (both annual report and corporate websites). Celik et al. (2006: 108) and Marston and Polei (2004: 293) argue that larger companies are more complex and have higher information asymmetry between managers and shareholders, that motivate them to disclosure more information than smaller companies. The political cost hypothesis predicts that larger companies have a stronger motivation to improve corporate reputation and public image, as they are more publicly visible (Celik et al., 2010: 108) and attract the attention of government bodies (Debreceny, Gray \& Rahman, 2002).

Larger companies are further expected to disclose more information, given the assumption that the relative costs of information production are lower for larger companies (Marston \& Polei, 2004: 294; Bollen, Hassink \& Bozic, 2006: 281; Trabelsi, Labelle \& Dumontier, 2008; Ashbaugh, Johnstone \& Warfield, 1999; Oyelere, Laswad \& Fisher, 2003) and as larger companies simply have more to disclose compared to smaller companies (Aly, Simon \& Hussainey, 2010: 185).

\section{Leverage}

Agency theory is often used to hypothesise a positive association between disclosure and leverage. Debreceny et al.
(2002) argued that an increase in the debt-equity ratio creates agency costs and, according to Aly et al. (2010: 186), companies could voluntarily disclose information on corporate websites to allow creditors to constantly monitor the company in assessing the ability of the company to repay its debts.

Xiao, Yang and Chow (2004: 209) noted that as the risk of default increases with leverage, lenders and shareholders would demand more information to assess the company's health. Larrán and Giner (2002: 66) argued that by increasing disclosure levels, a company can reduce agency costs and the possible conflicts between shareholders and creditors.

Research to date reports positive; negative; and no association between disclosure and leverage. Xiao et al. (2004: 215), Celik et al. (2006), and Ismail (2002) all reported a positive association. Cormier, Ledoux and Magnan (2009: 8) reported a negative association. The following studies, however, reported no significant association: Aly et al. (2010: 191), Bollen et al. (2006: 291), Debreceny et al. (2002), Froidevaux (2004), Almilia (2009: 95), Larrán and Giner (2002), and Oyelere et al. (2003).

\section{Current ratio}

Leverage and the current ratio are both risk measures, but where increased leverage is associated with increased risk, increase in the current ratio is associated with decreased risk. Oyelere et al. (2003) found a positive association, while Aly et al. (2010: 186), and Leventis and Weetman (2004: 240) found no significant association between disclosure and the current ratio.

\section{Financial performance}

Signalling theory can be used to hypothesise a positive association between disclosure and financial performance. Companies with good news are more likely to disclose more information compared to companies with bad news (Aly et al., 2010: 185). Profitable companies have an incentive to distinguish themselves from less successful companies in order to raise capital at the lowest possible price (Marston \& Polei, 2004: 294). Lev and Penman (1990), and Ettredge, Richardson and Scholz (2002) pointed out that the absence of voluntary disclosure may be perceived as "bad news" about a company. Larrán and Giner (2002: 66) argued that increased disclosure associated with profitability could be seen as a mechanism to improve the image of the company, to secure directors' job security and to improve their remuneration.

Celik et al. (2006: 110), Aly et al. (2010: 185) and Trabelsi et al. (2008) pointed to the mixed results reported in the literature and listed research that found both positive and negative associations. Positive associations were reported by Froidevaux (2004), Celik et al. (2006), Aly et al. (2010) and Pirchegger and Wagenhofer (1999) (Austrian sample).

On the other hand, Ashbaugh et al. (1999), Ettredge et al. (2002: 366), Marston and Polei (2004), Oyelere et al. (2003), 
Pirchegger and Wagenhofer (1999) (German sample), Xiao et al. (2004: 215), Larrán and Giner (2002), Abdelsalam, Bryant and Street (2007), Bollen et al. (2006: 291), Cormier et al. (2009) and Leventis and Weetman (2004) all document no significant association between financial performance and disclosure.

\section{Market to book}

The market to book ratio compares the market's valuation of a company to the book value of the company as reflected in its financial statements. Larrán and Giner (2002: 67) argued that as higher market-to-book ratios are associated with higher amounts of intangibles that is not recorded in the financial statements of companies, there will be a greater motivation for such companies to disclose more information to ensure that the company is properly valued. Celik et al. (2006: 110) state that companies with high growth prospects and large intangible assets have specific knowledge that is not effectively and efficiently transferable to investors through conventional accounting disclosures.

Significant positive associations were reported by Cormier $e t$ al. (2009) and Orens, Aerts and Cormier (2010), as opposed to Bollen et al. (2006: 291) and Abdelsalam et al. (2007: 24) who reported significant negative associations. Froidevaux (2004), Celik et al. (2006), Trabelsi et al. (2008) and Larrán and Giner (2002), on the other hand, all reported no significant association between the market-to-book ratio and disclosure levels.

\section{Financing activities}

Cormier et al. (2009: 8) argued that companies that access capital markets on a continuous basis have more pressure to disclose relevant information more regularly, as investors and lenders dislike any unpleasant surprises. Cormier et al. (2009: 16) documented a highly positive association at the $1 \%$ level between their measure of capital market reliance ${ }^{3}$ and webbased performance disclosure.

Trabelsi et al. (2008) also reported a significant positive association (although only at the $10 \%$ significance level) between their measure of financing activities ${ }^{4}$ and incremental ${ }^{5}$ voluntary website disclosure. Xiao et al. (2004), on the other hand, reported no significant association between their proxy for financing activities and the total disclosure score, and a not expected, significant negative association at the $5 \%$ level for a voluntary disclosure sub-category.

\section{Big four audit}

Xiao et al. (2004: 200) as well as Wang, O and Claiborne (2008: 18) argued that both agency and signalling theory support the hypothesis that increased levels of IIR are

\footnotetext{
${ }^{3}$ Dummy variable of one for year-to-year change of more than $20 \%$ in the debt to market value equity ratio.

${ }^{4}$ Dummy variable of one if any new debt/equity has been issued in the prior three years.
}

expected for companies that are audited by one of the big four audit companies.

Knowing that larger auditing companies usually demand more detailed disclosure, the engagement of a big four auditor is a signal to shareholders and the investment community of their acceptance of such demands. Xiao et al. (2004: 201) proposed that international audit companies are more likely to facilitate the use of innovative IIR practices. Larger audit companies further have more to lose from damage to their reputations and are therefore likely to call for more extensive disclosures.

Xiao et al. (2004: 215) reported a positive association between audit quality and the level of voluntary disclosure via corporate websites, but no significant associations between the total disclosure score, content, presentation or mandatory scores. Aly et al. (2010: 187) cited research that reported, respectively, positive and no association between disclosure and being audited by a big four audit company.

\section{Industry}

Aly et al. (2010: 187) used signalling theory to explain an association between industry type and disclosure. If a company within an industry discloses less information compared to industry peers it may be interpreted as a signal that the company is hiding bad news. This trend of companies to disclose similar information as industry peers is often referred to in the literature as the 'follower's effect' (e.g. Lybaert, 2002).

Studies that have examined the corporate website as disclosure vehicle showed conflicting results. Abdelsalam et al. (2007), Pervan (2006), Lybaert (2002), Celik et al. (2006), Aly et al. (2010), Bonsón and Escobar (2002; 2006), Ettredge, Richardson and Scholz (2001), and Xiao et al. (2004: 202) all reported an association as opposed to Trabelsi et al. (2008), Larrán and Giner (2002), Geerings, Bollen and Hassink (2003), Oyelere et al. (2003) and Bollen et al. (2006), who reported no significant association.

\section{Listing status}

A foreign listing will extend the dispersion of shareholders and therefore increase information asymmetry (Bollen et al., 2006: 278; Kang \& Stulz, 1997). Disclosure can decrease these information asymmetries (Marston \& Polei, 2004: 295; Debreceny et al., 2002). Extensive voluntary disclosure via corporate websites can also create the impression of greater transparency (Xiao et al., 2004: 201), which may be important for foreign investors.

On another point, Cooke (1992) and Xiao et al. (2004) argued that companies with listings on a foreign stock exchange face additional disclosure requirements and would therefore

\footnotetext{
${ }^{5}$ Incremental disclosure was defined as disclosure additional to SEDAR (i.e. mandatory) disclosure requirements.
} 
disclose more information than companies not subject to these additional requirements. Bollen et al. (2006: 278) emphasised that for companies to communicate with local and foreign stakeholders (e.g. customers, consumers, corporate partners or investors) a communication channel, such as the corporate website that can simultaneously provide identical information to all interested stakeholders, is needed.

A number of studies to date have documented an association between disclosure (as measured via printed media, e.g. hard copy annual reports) and the number of listings or a listing on a US or UK stock exchange (Celik et al., 2006: 109). A positive association between corporate website disclosure and listing status was reported by Xiao et al. (2004), Debreceny et al. (2002), Bollen et al. (2006: 291) and Aly et al. (2010: 191). Oyelere et al. (2003), on the other hand, found no association between website disclosure and listing status. Ali (2010), as cited by Khan and Ismail (2012: 7), documented a positive association between listing age and website disclosure.

\section{Ownership}

Retail investors have less access to information compared to institutional investors that may obtain information more easily from internal sources within the company. According to Marston and Polei (2004: 294), it could be assumed that investors with relative smaller shareholdings will use corporate websites to gather company-specific information as other information sources may be more inaccessible than they are for the larger shareholders.

According to Ho and Wong (2001) and Marston and Polei (2004: 294), agency theory dictated that in a dispersed ownership shareholder structure, companies will disclose more information to reduce agency cost and information asymmetry. Proxies such as the number of shareholders (e.g. Pervan, 2006) and free float percentage (e.g. Celik et al., 2006) could be used to proxy for ownership dispersion.

Some studies, however, developed a proxy to measure the opposite of shareholder dispersion, i.e. shareholder concentration. Orens et al. (2010) measured shareholder concentration as a dummy variable of one if companies had a single investor that had a $20 \%$ or more shareholding. Abdelsalam et al. (2007) used two proxies to measure shareholder concentration, namely the percentage of shares held by directors and the percentage of shares held by major shareholders. ${ }^{6}$

Directors who are also shareholders will have to bear both the consequences and benefits of the quality of management. Abdelsalam et al. (2007: 9) argued that high levels of director shareholdings align the interest of management and shareholders, which, in turn, reduces the need for additional voluntary disclosure to reduce agency costs.

According to Chau and Gray (2002) family-controlled companies have less motivation than companies that have wider ownership to disclose more information, given their relative weak demand for public disclosure. Trabelsi et al. (2008) argued that companies with a concentrated ownership may want to preserve that information advantage by not using disclosure channels such as corporate websites.

Literature measuring disclosure using the printed media as disclosure vehicle reports conflicting results. For example, Chau and Gray (2002) found a positive association between ownership dispersion and voluntary disclosure compared to Raffournier (1995), who reported a non-significant relationship.

More specifically, in regard to studies that measured corporate websites as disclosure vehicle, Orens et al. (2010) and Abdelsalam et al. (2007) reported significant negative associations between disclosure and ownership concentration, but Trabelsi et al. (2008) and Cormier et al. (2009) reported no similar significant associations.

Regarding the association between disclosure and ownership dispersion, Bollen et al. (2006) reported a significant positive association from their univariate analysis, but reported no significant association following a multivariate analysis. Marston and Polei (2004) found a significant positive association for their 2000 sub-sample, but no significant association for their 2003 sub-sample from their multivariate analysis. Pervan (2006) reported a significant positive association for a Croatian sub-sample, but no significant association for a Slovene sub-sample.

\section{Method of statistical analysis}

For each company an IIR score was calculated by totalling the individual attribute scores. No weightings were assigned and the maximum available IIR score per company is therefore 346 .

Table 1 lists the independent variables used in the stepwise regression model-building, a brief description of how each variable was calculated, as well as the expected association with the dependent variable, IIR, based on the above literature review.

\footnotetext{
${ }^{6}$ Abdelsalam et al. (2007) defined major shareholders as all shareholders with a shareholding exceeding $5 \%$.
} 
Table 1: Independent variables - description and expected associations

\begin{tabular}{|c|c|c|}
\hline Variable & Description & $\begin{array}{l}\text { Predicted } \\
\text { direction }\end{array}$ \\
\hline \multicolumn{3}{|c|}{ Independent continuous variables } \\
\hline Company size & $\begin{array}{l}\text { Average daily market capitalisation of all trading days from } 1 \text { December } 2014 \text { to } 30 \text { November } \\
2015\end{array}$ & + \\
\hline Leverage & Ratio between debt and assets & + \\
\hline Current ratio & Ratio between current assets and current liabilities & - \\
\hline Financial performance & Ratio between profit to ordinary shareholders interest (ROE) & + \\
\hline Market-to-book & Ratio between the share price and the book value of equity & + \\
\hline Number of years listed & Number of years listed as on the date the IIR of each company was measured & + \\
\hline Director shareholding & The percentage direct and indirect, beneficial and non-beneficial shareholding of directors & - \\
\hline Free float & Ratio between the total issued shares minus restricted shares to the total issued shares & + \\
\hline \multicolumn{3}{|c|}{ Independent categorical variables } \\
\hline Net issue of shares & $\begin{array}{l}\text { Dummy variable representing one if the company on net has issued shares in the preceding } 12 \text { - } \\
\text { month period }\end{array}$ & + \\
\hline Net buy back of shares & $\begin{array}{l}\text { Dummy variable representing one if the company on net has bought back shares in the } \\
\text { preceding } 12 \text {-month period }\end{array}$ & - \\
\hline Big four audit & $\begin{array}{l}\text { Dummy variable representing one if the company is audited by either PwC, KPMG, Deloitte } \\
\text { \& Touche or Ernst \& Young }\end{array}$ & + \\
\hline JSE industry & JSE industry classification & $+1-$ \\
\hline Dual listing & $\begin{array}{l}\text { Dummy variable representing one if the company is dually listed on the JSE and any other } \\
\text { stock exchange }\end{array}$ & + \\
\hline Primary listing & Dummy variable representing one if the company has a primary listing other than the JSE & + \\
\hline Block ownership & Dummy variable representing one if one shareholder has more than $20 \%$ of issued shares & - \\
\hline
\end{tabular}

All independent variables were captured from the INET BFA database, a reputable supplier of financial data in South Africa, with the exception of the audit variable that was captured from the audit report in the latest financial statements $^{7}$ and the JSE industry, dual listing, primary listing, years listed and free float that were obtained directly from the JSE.

\section{Results}

\section{IIR measurement results}

Figure 1 shows the variation in the IIR score over the 85 companies. The minimum and maximum IIR scores are 13.5 and 193.5 respectively, with $71 \%$ of scores falling between 45 and 135, and only three scores in each of the lower and upper categories. The average IIR score is 98 and the median 96.

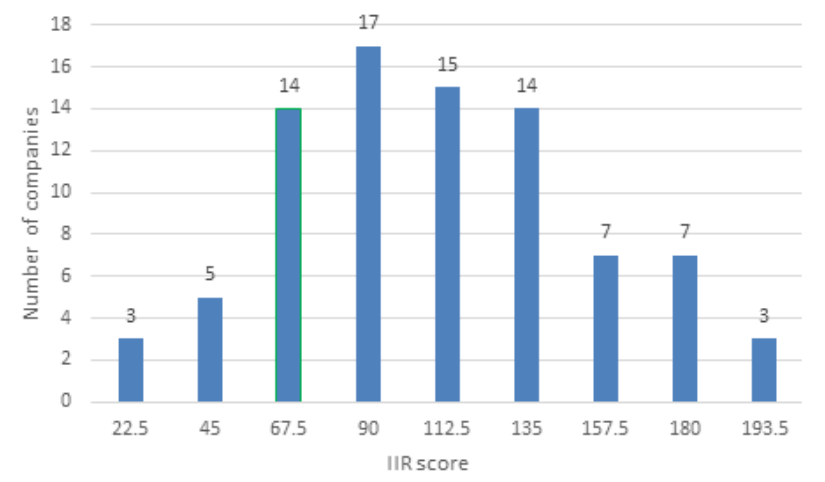

Figure 1: Distribution of Internet investor relations scores over companies

\footnotetext{
${ }^{7}$ As available on 30 September 2015.
}

From Figure 1, the following is evident: a significant crosssectional variation exists between the IIR scores of JSE-listed companies and none of the companies examined in this study achieved a $100 \%$ IIR score.

The voluntary nature of IIR may be offered as an explanation of the evident cross-sectional variation. Pirchegger and Wagenhofer (1999: 391) argued that it is not obvious that companies would wish to achieve their maximum disclosure score, nor that users of their corporate websites would want the company to achieve the maximum score. According to Lybaert (2002: 220), companies trade off the benefits and costs of using corporate websites to communicate with investors, with various internal and external factors that can influence a company's decision as to how much to invest in the development of an IIR presence. Further to the reasons offered by Pirchegger and Wagenhofer (1999) and Lybaert (2002), the following can be offered as possible reasons that none of the companies achieved a $100 \%$ IIR score:

- The measurement instrument used aimed to measure as widely as possible and it may be argued that many attributes are only 'nice to haves', for example, E-reader (dynamic or interactive PDF documents), Excel downloads, and Webcasts, podcasts and transcripts of presentations;

- Attributes may be deliberately ignored by companies, as they may argue that these attributes are readily available elsewhere (e.g. SENS (Stock Exchange News Service) and share price information) or are already included in their integrated annual report (e.g. shareholder information, company advisors, corporate governance, and corporate responsibility information); 
- Some attributes may be viewed by companies as alternatives in the development of their corporate website, for example, the search function, sitemap and help function as navigation tool or the use of an e-mail alert service and RSS content feed to improve the timeliness of information communicated to investors; and

- Finally, some attributes measured in this study, for example, dividend reinvestment plan, American Depository Receipt programme and information on listed debt instruments may not be applicable to all companies.

\section{Selected descriptive statistics}

The descriptive statistics are set out in Table 2. For three independent variables (market capitalisation, market-to-book ratio, and the number of years listed), the natural logarithm was used to reduce the skewness in the distribution of these variables. Statistics for these variables are presented prior to the natural logarithmic transformations, which were used in the stepwise regression analysis.

Table 2: Descriptive statistics: Variables used to examine variations in IIR

\begin{tabular}{|c|c|c|c|c|c|c|c|}
\hline \multicolumn{8}{|c|}{ Panel A: Continuous independent variables } \\
\hline & \multirow[t]{2}{*}{ Average } & \multirow[t]{2}{*}{ Min } & \multicolumn{3}{|l|}{ Quartile } & \multirow[t]{2}{*}{ Max } & \multirow{2}{*}{$\begin{array}{l}\text { Standard } \\
\text { deviation }\end{array}$} \\
\hline & & & Q1 & Q2 & Q3 & & \\
\hline Size (ZAR' 000000$)$ & 49409.17 & 38.67 & 584.88 & 6247.90 & 25944.84 & 1411045.16 & 169730.55 \\
\hline Leverage & 0.45 & 0 & 0.28 & 0.40 & 0.61 & 1.21 & 0.25 \\
\hline Current ratio & 5.07 & 0.03 & 0.99 & 1.32 & 1.94 & 159.31 & 22.52 \\
\hline $\begin{array}{l}\text { Financial performance } \\
\text { (ROE) }\end{array}$ & 11.03 & -40.09 & 2.78 & 12.77 & 20.62 & 84.02 & 21.14 \\
\hline Market-to-book & 2.28 & 0.13 & 0.89 & 1.43 & 2.88 & 12.99 & 2.53 \\
\hline Number of years listed & 22.75 & 1.78 & 8.94 & 17.19 & 27.58 & 75.23 & 17.99 \\
\hline Director shareholding (\%) & 13.88 & 0.00 & 0.10 & 2.87 & 23.13 & 81.79 & 20.47 \\
\hline Free float $(\%)$ & 59.70 & 2.50 & 36.00 & 60.00 & 87.00 & 100.00 & 28.63 \\
\hline
\end{tabular}

\begin{tabular}{l|c|c|c|}
\hline & Yes $(1)$ & No $(0)$ & Total \\
\hline Net issue of shares & 36 & 49 & 85 \\
\hline Net buy back of shares & 15 & 70 & 85 \\
\hline Big four audit & 61 & 24 & 85 \\
\hline Dual listing & 25 & 60 & 85 \\
\hline Primary listing (other JSE) & 14 & 71 & 85 \\
\hline Block ownership & 52 & 33 & 85 \\
\hline Basic material industry & 17 & 68 & 85 \\
\hline Consumer goods industry & 7 & 78 & 85 \\
\hline $\begin{array}{l}\text { Consumer services } \\
\text { industry }\end{array}$ & 10 & 75 & 85 \\
\hline Financial industry & 21 & 64 & 85 \\
\hline Healthcare industry & 3 & 82 & 85 \\
\hline Industrials industry & 19 & 66 & 85 \\
\hline Oil and gas industry & 1 & 84 & 85 \\
\hline Technology industry & 4 & 81 & 85 \\
\hline $\begin{array}{l}\text { Telecommunications } \\
\text { industry }\end{array}$ & 2 & 83 & 85 \\
\hline Utilities industry & 1 & 84 & 85 \\
\hline
\end{tabular}

The average leverage was 0.45 . As this ratio was smaller than 0.5 , it showed that on average the assets of the sample companies were primarily financed through equity. Although the current ratio varied between as low as 0.03 to a maximum of 159.31 , it should be noted that only three companies had a current ratio of more than 5 .

The average company was profitable, with an average return on equity (ROE) of just over $11 \%$. As suggested by the average $(11.03 \%)$ and the median $(12.77 \%)$, ROE appears to be normally distributed.

The average company was listed on the JSE for nearly 23 years, with $25 \%$ of the companies listed for more than 27 years and $25 \%$ listed for less than nine years. Twenty-five companies had a dual listing and 14 companies had only a secondary listing on the JSE. Regarding financing activities, 36 companies on net issued shares during 2015, and 15 companies on net bought back shares.

On average, $13.88 \%$ of shares were held by directors. Directors' shareholding varied significantly, with $25 \%$ of companies where directors had almost no shares (less than $0.1 \%$ of issued shares) as opposed to $25 \%$ of companies where directors held about one quarter of issued shares. Similar variations were evident in an analysis of the distribution of the free float percentage. Of the 85 companies 
in the sample, 52 had a single shareholder who owned more than $20 \%$ of the issued shares.

Although, the majority of the companies were audited by PwC, KPMG, Deloitte \& Touche or Ernst \& Young, almost $30 \%$ were audited by smaller audit companies.

\section{Correlation analysis}

Table 3 shows the Pearson correlation coefficients between IIR and the independent variables examined. According to Table 3, company size, leverage, being audited by a big four audit company, having a dual listing, directors' shareholding, free float and blockholder ownership are all statistically significantly correlated at the $5 \%$ or better level with IIR. All coefficients are as expected.

Table 3: Correlation matrix: IIR and independent variables

\begin{tabular}{|c|c|}
\hline Independent variable & IIR \\
\hline Company size & $0.65 * * *$ \\
\hline Leverage & $0.37 * * *$ \\
\hline Current ratio & -0.12 \\
\hline Financial performance (ROE) & 0.10 \\
\hline Market-to-book value & 0.12 \\
\hline Net issue of shares & $0.21 *$ \\
\hline Net buy back of shares & -0.09 \\
\hline Big four audit & $0.44 * * *$ \\
\hline JSE Industry - Basic material & 0.06 \\
\hline JSE Industry - Consumer goods & -0.07 \\
\hline JSE Industry - Consumer services & -0.09 \\
\hline JSE Industry - Financials & -0.01 \\
\hline JSE Industry - Healthcare & 0.03 \\
\hline JSE Industry - Industrials & 0.01 \\
\hline JSE Industry - Oil and gas & 0.03 \\
\hline JSE Industry - Technology & -0.05 \\
\hline JSE Industry - Telecommunications & $0.22 * *$ \\
\hline JSE Industry - Utilities & -0.08 \\
\hline Dual listing & $0.26 * *$ \\
\hline Primary listing & 0.15 \\
\hline Years listed & $0.19 *$ \\
\hline Director shareholding & $-0.30 * * *$ \\
\hline Free float & $0.37 * * *$ \\
\hline Block ownership & $-0.27 * *$ \\
\hline
\end{tabular}

Table 4 shows Pearson correlation coefficients between independent variables. Only two correlations in Table 4 are significantly higher than 0.5 . The correlation between the market-to-book ratio and the return on equity $(0.54)$ and the correlation between dual listing and primary listing (0.69). The high correlation between dual listing and primary listing was expected as 14 of the 25 companies with a dual listing also have a primary listing other than the JSE. 
Table 4: Correlation matrix: independent variables used to examine variations in IIR

\begin{tabular}{|c|c|c|c|c|c|c|c|c|c|c|c|c|c|c|c|c|c|c|c|c|c|c|c|c|}
\hline & 思 & 勇 & 总 & : & $\underline{\underline{E}}$ & 氙 & 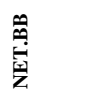 & $\frac{5}{8}$ & 㐫 & تُ & E & is & \pm & - & ర్ & 炭 & 要 & $D$ & 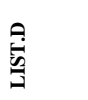 & $\begin{array}{l}\stackrel{4}{0} \\
\frac{2}{3}\end{array}$ & 帘 & 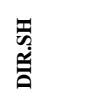 & ب & $\begin{array}{l}\text { ज्ञ } \\
\stackrel{0}{0} \\
\stackrel{0}{0}\end{array}$ \\
\hline SIZE & 1.00 & & & & & & & & & & & & & & & & & & & & & & & \\
\hline LEV & $0.28^{* * *}$ & 1.00 & & & & & & & & & & & & & & & & & & & & & & \\
\hline CUR & -0.02 & $-0.30^{* * *}$ & 1.00 & & & & & & & & & & & & & & & & & & & & & \\
\hline ROE & $0.41^{* *}$ & 0.06 & $0.44^{* * *}$ & 1.00 & & & & & & & & & & & & & & & & & & & & \\
\hline MTB & $0.49^{* * *}$ & $0.27^{* *}$ & $\begin{array}{c}-0.07 \\
\end{array}$ & $0.54^{* * *}$ & 1.00 & & & & & & & & & & & & & & & & & & & \\
\hline NET.ISS & $0.41^{* * *}$ & -0.03 & 0.04 & 0.13 & $0.33 * *$ & 1.00 & & & & & & & & & & & & & & & & & & \\
\hline NET.BB & 0.02 & 0.01 & \begin{tabular}{c|}
-0.08 \\
\end{tabular} & 0.00 & $\begin{array}{c}-0.02 \\
\end{array}$ & $-0.40^{* * *}$ & 1.00 & & & & & & & & & & & & & & & & & \\
\hline $\begin{array}{l}\text { AUDIT } \\
\end{array}$ & $0.42^{* * *}$ & 0.07 & 0.09 & $0.27^{* * *}$ & 0.14 & 0.11 & $-0.26^{* * *}$ & 1.00 & & & & & & & & & & & & & & & & \\
\hline BM & $-0.23^{* *}$ & $-0.25^{* * *}$ & 0.11 & $-0.25 * *$ & $-0.38^{* *}$ & $-0.25^{* *}$ & 0.00 & 0.12 & 1.00 & & & & & & & & & & & & & & & \\
\hline CG & 0.12 & 0.09 & -0.05 & 0.02 & 0.14 & 0.00 & -0.14 & 0.00 & -0.15 & 1.00 & & & & & & & & & & & & & & \\
\hline CS & 0.16 & $0.19^{*}$ & $\begin{array}{c}-0.06 \\
\end{array}$ & $0.29^{* * *}$ & $0.49^{* * *}$ & 0.13 & -0.17 & $0.23^{* *}$ & $-0.18^{*}$ & -0.11 & 1.00 & & & & & & & & & & & & & \\
\hline $\mathrm{F}$ & $0.27^{* * *}$ & -0.06 & 0.09 & 0.17 & 0.08 & $0.23^{* * *}$ & 0.16 & 0.06 & $-0.29^{* * *}$ & -0.17 & $-0.21^{*}$ & 1.00 & & & & & & & & & & & & \\
\hline $\mathrm{H}$ & -0.01 & 0.07 & -0.03 & -0.03 & 0.10 & $0.22^{* * *}$ & -0.09 & -0.02 & -0.10 & -0.06 & -0.07 & -0.11 & 1.00 & & & & & & & & & & & \\
\hline I & $-0.23^{* *}$ & 0.03 & \begin{tabular}{c|}
-0.08 \\
\end{tabular} & -0.14 & $-0.22^{* * *}$ & -0.17 & 0.12 & $-0.29^{* * *}$ & $-0.27^{* * *}$ & $\begin{array}{c}-0.16 \\
\end{array}$ & $-0.20^{*}$ & $-0.31^{* * *}$ & \begin{tabular}{c|}
-0.10 \\
\end{tabular} & 1.00 & & & & & & & & & & \\
\hline OG & -0.06 & -0.08 & $\begin{array}{c}-0.02 \\
\end{array}$ & $-0.24 * *$ & -0.03 & -0.09 & -0.05 & 0.07 & -0.05 & $\begin{array}{l}-0.03 \\
\end{array}$ & $\begin{array}{l}-0.04 \\
\end{array}$ & $\begin{array}{c}-0.06 \\
\end{array}$ & \begin{tabular}{c|}
-0.02 \\
\end{tabular} & -0.06 & 1.00 & & & & & & & & & \\
\hline TEC & -0.07 & 0.10 & -0.03 & 0.04 & 0.03 & 0.03 & -0.10 & -0.11 & -0.11 & -0.07 & \begin{tabular}{|c|}
-0.08 \\
\end{tabular} & -0.13 & \begin{tabular}{c|}
-0.04 \\
\end{tabular} & -0.12 & -0.02 & 1.00 & & & & & & & & \\
\hline TEL & $0.21^{*}$ & -0.01 & -0.03 & 0.06 & 0.06 & 0.02 & 0.13 & 0.10 & -0.08 & -0.05 & -0.06 & $\begin{array}{l}-0.09 \\
\end{array}$ & $\begin{array}{l}-0.03 \\
\end{array}$ & \begin{tabular}{c|}
-0.08 \\
\end{tabular} & -0.02 & $\begin{array}{l}-0.03 \\
\end{array}$ & 1.00 & & & & & & & \\
\hline U & $\begin{array}{c}-0.19^{*} \\
\end{array}$ & 0.00 & -0.02 & -0.04 & -0.15 & -0.09 & -0.05 & -0.17 & -0.05 & $\begin{array}{c}-0.03 \\
\end{array}$ & $\begin{array}{l}-0.04 \\
\end{array}$ & -0.06 & -0.02 & \begin{tabular}{c|}
-0.06 \\
\end{tabular} & -0.01 & \begin{tabular}{c|}
-0.02 \\
\end{tabular} & -0.02 & 1.00 & & & & & & \\
\hline LIST.D & $0.20^{*}$ & -0.09 & $0.24^{* * *}$ & -0.10 & -0.13 & 0.18 & -0.10 & 0.18 & $0.32 * *$ & $\begin{array}{l}-0.01 \\
\end{array}$ & $\begin{array}{l}-0.16 \\
\end{array}$ & 0.11 & \begin{tabular}{c|}
-0.12 \\
\end{tabular} & $-0.35^{* * *}$ & 0.17 & $\begin{array}{l}-0.02 \\
\end{array}$ & 0.07 & 0.17 & 1.00 & & & & & \\
\hline LIST.P & 0.16 & -0.03 & 0.15 & -0.09 & -0.12 & $0.20^{*}$ & -0.12 & 0.00 & 0.17 & 0.10 & -0.16 & $0.19^{*}$ & \begin{tabular}{c|}
-0.08 \\
\end{tabular} & $-0.24^{* * *}$ & -0.05 & -0.10 & -0.07 & $0.25 * *$ & $0.69 * *$ & 1.00 & & & & \\
\hline LIST.Y & 0.16 & 0.07 & 0.10 & 0.14 & $\begin{array}{c}-0.02 \\
\end{array}$ & $-0.23^{* *}$ & 0.16 & $0.31^{* *}$ & 0.14 & -0.03 & 0.15 & -0.16 & -0.06 & -0.03 & 0.03 & 0.02 & -0.01 & -0.08 & -0.07 & $-0.37^{* * *}$ & 1.00 & & & \\
\hline DIR.SH & $-0.35^{* * *}$ & 0.00 & 0.04 & -0.07 & $\begin{array}{c}-0.08 \\
\end{array}$ & -0.11 & 0.09 & $-0.25^{* *}$ & -0.15 & 0.06 & $\begin{array}{l}-0.09 \\
\end{array}$ & -0.16 & 0.18 & $0.30^{* * *}$ & -0.07 & 0.06 & -0.10 & -0.07 & $-0.31^{* *}$ & -0.17 & -0.06 & 1.00 & & \\
\hline F.FLT & $0.39 * *$ & 0.02 & 0.03 & $0.19^{*}$ & 0.03 & $0.20^{*}$ & -0.12 & $0.26 * *$ & -0.06 & $-0.18^{*}$ & 0.13 & 0.09 & \begin{tabular}{c|}
-0.04 \\
\end{tabular} & 0.02 & $\begin{array}{l}-0.14 \\
\end{array}$ & 0.05 & 0.09 & -0.15 & -0.05 & \begin{tabular}{c|}
-0.14 \\
\end{tabular} & 0.15 & -0.39 ** & 1.00 & \\
\hline $20 \% . \mathrm{SH}$ & $-0.34 * *$ & $-0.20^{*}$ & 0.12 & -0.17 & $-0.33^{* *}$ & $-0.29^{* * *}$ & 0.12 & -0.02 & 0.16 & $\begin{array}{l}-0.02 \\
\end{array}$ & -0.16 & 0.06 & -0.11 & -0.04 & 0.09 & -0.05 & -0.04 & 0.09 & -0.07 & $-0.23^{* *}$ & $0.21^{*}$ & 0.16 & $-0.32^{* * *}$ & 1.00 \\
\hline
\end{tabular}




\section{Regression estimation results}

Table 5 presents the result of the stepwise regression that was performed using the IIR score as dependent, and the independent variables as listed and described in Table 1.

\section{Table 5: Regression results}

\begin{tabular}{l|r}
\hline & \multicolumn{1}{l}{ IIR } \\
\hline$\beta_{0}$ & $-151.91^{* * *}$ \\
\hline Company size & $9.69^{* * *}$ \\
\hline Leverage & $51.66^{* * *}$ \\
\hline Big four audit & $21.45^{* * *}$ \\
\hline JSE Industry - Consumer services & $-52.99^{* * *}$ \\
\hline JSE Industry - Consumer goods & $-37.92^{* * *}$ \\
\hline JSE Industry - Financials & $-32.16^{* * *}$ \\
\hline JSE Industry - Technology & $-21.89^{* *}$ \\
\hline Free float & $20.18^{*}$ \\
\hline Dual listing & $10.79^{*}$ \\
\hline Adjusted R ${ }^{2}$ & $68.76 \%$ \\
\hline F-value & 21.55 \\
\hline Durbin-Watson & 2.26 \\
\hline *** significant at the 1\% level; ** significant at the 5\% level; * significant
\end{tabular}
at the $10 \%$ level

As depicted in Table 5, company size, leverage, being audited by a big four audit company, JSE industry membership, free float, and dual listing are explanatory factors that explain the level of IIR. As expected, coefficients for company size, leverage and being audited by a big four audit company were positive.

As discussed, almost all prior studies showed a significant positive association between disclosure and company size. Froidevaux (2004), Bollen et al. (2006) and Orens et al. (2010) all document a significant positive association between website disclosure and company size.

Agency theory is often used in the literature as underlying theoretical foundation to hypothesise a positive association between disclosure and leverage (Debreceny et al., 2002; Xiao et al., 2004 and Larrán \& Giner, 2002). As opposed to the association between disclosure and size, empirical research to date has produced mixed results on the association between disclosure and leverage. Following Xiao et al. (2004: 215) and Celik et al. (2006), this study provides further support for a positive association between website disclosure and leverage.

Signalling theory and agency theory both support the hypothesis of a positive association between disclosure and being audited by a big four audit company. The positive association found in this study between IIR and being audited by a big four audit company do provide support for Xiao et al. (2004), Bonsón and Escobar (2002) and Wang et al. (2008).

Companies tended to disclose information similar to that disclosed by their industry peers. More specifically, the results in Table 5 showed that lower IIR levels can be expected from companies categorised as constituents of the consumer goods, consumer services, financial, and technology JSE industries rather than other JSE industries.

Also as expected, coefficients for the free float percentage and the dual-listed dummy variable were positive, but only statistically significant at the $10 \%$ level. Marston and Polei (2004) also found a significant positive association between free float and website disclosure for their 2000 sub-sample, but found no association for their 2003 sub-sample. A positive association between having a dual listing and website disclosure was reported by Xiao et al. (2004), Debreceny et al. (2002), Bollen et al. (2006: 291) and Aly et al. (2010: 191).

The magnitude of the reported adjusted $\mathrm{R}^{2}$ of $68.76 \%$ compared favourably to studies such as Almilia (2009) that reported an adjusted $\mathrm{R}^{2}$ of $47.6 \%$; Leventis and Weetman (2004) (35.6\%); Celik et al. (2006) (33\%); Marston and Polei (2004) (61.7\%); Trabelsi et al. (2008) (35.42\%); Aly et al. (2010) (70\%); Cormier et al. (2009) (27.9\%); Ettredge et al. (2002) (17.5\%); Bollen et al. (2006) (21.1\%); Pervan (2006) (69\%); Xiao et al. (2004) (11\%); Abdelsalam et al. (2007) (35.8\%); Larrán and Giner (2002) (33.2\%), and Bonsón and Escobar (2006) (50\%).

A minimum tolerance value of 0.5 and a Durbin-Watson test statistic of 2.26 confirmed the absence of respectively multicollinearity and autocorrelation. All residuals were approximately normally distributed and no evidence of heteroscedasticity was found.

\section{Summary and conclusion}

The purpose of this study was to establish the determinants of IIR quality. IIR were measured for a sample of 85 companies using a measurement instrument that consists of 346 attributes. Overall, the majority of companies did not use corporate websites optimally to communicate with investors.

From the literature, the following company characteristics were identified that could explain variations in IIR levels: company size, leverage, the current ratio, financial performance (return on equity), market-to-book value, number of years listed, directors' shareholding percentage, free float percentage, financing activities (i.e. issue or buy back of shares), auditors, industry membership, dual listing status, primary listing and the existence of block ownership.

Stepwise regression was applied to develop a regression model that best explains variations in IIR levels, using the company characteristics listed in the paragraph above as independent variables and the IIR score per company as dependent variable. The following were found to be significant independent variables as determinants of IIR quality: company size, leverage, being audited by a big four audit company, JSE industry membership, free float percentage and dual listing status.

More specifically, larger companies, companies with more debt, companies that are audited by a big four audit company, 
companies with a higher free-float percentage (i.e. fewer restricted shares) and, lastly, companies that were dual-listed had higher IIR scores. Companies that were members of one of the following four JSE industries, namely consumer services, consumer goods, financials, and technology, each had a lower IIR score compared to companies listed in one of the other nine industries.

An understanding of IIR is important for standard setters and regulatory bodies such as SAICA and the JSE. The results of the study specifically contribute to investor relations and accounting literature.

Though the utmost care was taken in measuring corporate websites, it is possible that some attributes might have been overlooked, given the complexity (e.g. number of internal hyperlinks) and the variety of website layouts. Although it is admitted that not all attributes measured may be applicable to all companies, the measurement instrument used made no attempt to distinguish between companies with respect to the relevancy or not of such attributes. Future research should consider the calculation of a unique score per company by removing attributes which are not applicable for some companies, and then calculate their IIR using the lower score.

Based on the investor recognition hypothesis (Merton, 1987), a well-developed investor relations strategy will increase company visibility, which in turn leads to increased share liquidity (Brown \& Hillegeist, 2007). Economic theory links increased liquidity to the cost of capital through information asymmetry (Botosan, 2000). This warrants the need for future research to examine the association between IIR and information asymmetry and the cost of capital, using data from JSE listed companies.

\section{REFERENCES}

Abdelsalam, O.H., Bryant, S.M. \& Street, D.L. 2007. 'An examination of the comprehensiveness of corporate Internet reporting provided by London-listed companies', Journal of International Accounting Research, 6(2): 1-33.

Ali, I. 2010. Internet financial reporting: A review of the literature and further evidence from New Zealand. Paper presented at the ARA Conference, Adelaide Australia, 2010.

Almilia, L.S. 2009. 'Determining factors of Internet financial reporting in Indonesia', Accounting and Taxation, 1(1): 87-99.

Aly, D., Simon, J. \& Hussainey, K. 2010. 'Determinants of corporate Internet reporting: Evidence from Egypt', Managerial Auditing Journal, 25(2): 182-202.

Ashbaugh, H., Johnstone, K.M. \& Warfield, T.D. 1999. 'Corporate reporting on the Internet', Accounting Horizons, 13(3): 241-257.

Barac, K. 2004. 'Financial reporting on the Internet in South Africa', Meditari Accountancy Research, 12(1): 1-20.

Bollen, L., Hassink, H. \& Bozic, G. 2006. 'Measuring and explaining the quality of Internet investor relations activities: A multinational empirical analysis', International Journal of Accounting Information Systems, 7(4): 273-298.
Bonsón, E. \& Escobar, T. 2002. 'A survey on voluntary disclosure on the Internet. Empirical evidence from 300 European Union companies', The International Journal of Digital Accounting Research, 2(1): 27-51.

Bonsón, E. \& Escobar, T. 2006. 'Digital reporting in Eastern Europe: An empirical study', International Journal of Accounting Information Systems, 7(4): 299-318.

Botosan, C.A. 2000. 'Evidence that greater disclosure lowers the cost of equity capital', Journal of Applied Corporate Finance, 12(4): 60-69.

Brown, S. \& Hillegeist, S.A. 2007. 'How disclosure quality affects the level of information asymmetry', Review of Accounting Studies, 12(2): 443-477.

Celik, O., Ecer, A. \& Karabacak, H. 2006. 'Impact of firm specific characteristics on the web based business reporting: Evidence from the companies listed in Turkey', Problems and Perspectives in Management, 4(3): 100-133.

Chau, G.K. \& Gray, S.J. 2002. 'Ownership structure and corporate voluntary disclosure in Hong-Kong and Singapore', The International Journal of Accounting, 37(2): 247-265.

Cooke, T.E. 1992. 'The impact of size, stock market listing and industry type on disclosure in the annual reports of Japanese listed companies', Accounting and Business Research, 22(87): 229-237.

Cormier, D., Ledoux, M. \& Magnan, M. 2009. 'The use of web sites as a disclosure platform for corporate performance', International Journal of Accounting Information Systems, 10(1): 1-24.

Debreceny, R., Gray, G.L. \& Rahman, A. 2002. 'The determinants of Internet financial reporting', Journal of Accounting and Public Policy, 21(4-5): 371-394.

Esterhuyse, L. \& Wingard, C. 2016. 'An exploration of the online investor relations (IR) practices of companies listed on the Johannesburg Stock Exchange (JSE)', South African Journal of Economic and Management Sciences, 19(2): 215-231.

Ettredge, R., Richardson, V.J. \& Scholz, S. 2001. 'The presentation of financial information at corporate web sites', International Journal of Accounting Information Systems, 2(3): 149-168.

Ettredge, R., Richardson, V.J. \& Scholz, S. 2002. 'Dissemination of information for investors at corporate web sites', Journal of Accounting and Public Policy, 21(4-5): 357-369.

Froidevaux, E.A. 2004. Investor relations Internet disclosure and the cost of equity capital. Unpublished PhD dissertation. Switzerland: University of Fribourg. [online] http://ethesis.unifr.ch/ theses/downloads.php?file=FroidevauxE.pdf

Geerings, J., Bollen, L.H.H. \& Hassink, H.F.D. 2003. 'Investor relations on the Internet: A survey of the Euronext zone', European Accounting Review, 12(3): 567-579.

Ho, S.S.M. \& Wong, K.S. 2001. 'A study of the relationship between corporate governance structures and the extent of voluntary disclosure', Journal of International Accounting, Auditing and Taxation, 10(2): 139-156.

IRBA (Independent Regulatory Board for Auditors). 2016. South Africa retains pole position for auditing and reporting standards for 
seventh year in a row. [online] https://www.irba.co.za/newsheadlines/press-releases

Ismail, T.H. 2002. An empirical investigation of factors influencing voluntary disclosure of financial reporting on the Internet in the GCC countries. Working paper. Giza: Cairo University.

Kang, J-K. \& Stulz, R.M. 1997. 'Why is there a home bias? An analysis of foreign portfolio equity ownership in Japan', Journal of Financial Economics, 46(1): 3-28.

Khan, M.N.A.A. \& Ismail, N.A. 2012. 'A review of e-financial reporting research', Journal of Internet and e-business Studies, 2012(1): 1-16.

Larrán, M. \& Giner, B. 2002. 'The use of the Internet for corporate reporting by Spanish companies', The International Journal of Digital Accounting Research, 2(1): 53-82.

Lev, B. \& Penman, S.H. 1990. 'Voluntary forecast disclosure, nondisclosure, and stock prices', Journal of Accounting Research, 28(1): 49-76.

Leventis, S. \& Weetman, P. 2004. 'Voluntary disclosures in an emerging capital market: Some evidence from the Athens Stock Exchange', Advances in International Accounting, 17(1): 227-250.

Loxton, L. 2003. 'Beleggersverhoudinge op die Internet: 'n Ondersoek in Suid-Afrika', Meditari Accountancy Research, 11(1): 80-94.

Lybaert, N. 2002. 'Online financial reporting: An analysis of the Dutch listed firms', The International Journal of Digital Accounting Research, 2(4): 195-234.

Marston, C. \& Polei, A. 2004. 'Corporate reporting on the Internet by German companies', International Journal of Accounting Information Systems, 5(3): 285-311.

Merton, R.C. 1987. 'A simple model of capital market equilibrium with incomplete information', The Journal of Finance, 42(3): 483510 .

Nel, G.F. \& Baard, R. 2007. 'Do corporate web sites in Africa communicate investor information according to best practice guidelines?', South African Journal of Information Management, 9(3): 1-14.

Nel, G.F. \& Brummer, L.M. 2016. 'The development of a measurement instrument to measure the quality of Internet investor relations', South African Journal of Business Management, 47(4): $15-25$.

Orens, R., Aerts, W. \& Cormier, D. 2010. 'Web-based non-financial disclosure and cost of finance', Journal of Business Finance and Accounting, 37(9): 1057-1093.

Oyelere, P., Laswad, F. \& Fisher, R. 2003. 'Determinants of Internet financial reporting by New Zealand companies', Journal of International Financial Management and Accounting, 14(1): 26-63.

Pervan, I. 2006. 'Voluntary financial reporting on the Internet analysis of the practice of stock-market listed Croatian and Slovene joint stock companies', Financial Theory and Practice, 30(1): 1-27.
Pirchegger, B. \& Wagenhofer, A. 1999. 'Financial information on the Internet: A survey of the homepages of Austrian companies', The European Accounting Review, 8(2): 383-395.

Raffournier, B. 1995. 'The determinants of voluntary financial disclosure by Swiss listed companies', European Accounting Review, 4(2): 261-280.

Stainbank, L.J. 2000. 'The status of financial reporting on the Internet', Accountancy SA, April.

Trabelsi, S., Labelle, R. \& Dumontier, P. 2008. 'Incremental voluntary disclosure on corporate websites: Determinants and consequences', Journal of Contemporary Accounting and Economics, 4(2): 120-155.

Venter, J.M.P. 2002. 'A survey of current online reporting practices in South Africa', Meditari Accountancy Research, 10(1): 209-225.

Wang, K., O.S. \& Claiborne, M.C. 2008. 'Determinants and consequences of voluntary disclosure in an emerging market: Evidence from China', Journal of International Accounting, Auditing and Taxation, 17(1): 14-30.

Xiao, J.Z., Yang, H. \& Chow, C.W. 2004. 'The determinants and characteristics of voluntary Internet-based disclosures by listed Chinese companies', Journal of Accounting and Public Policy, 23(3): 191-225. 